\title{
APRENDIZAGEM DO NAUFRÁGIO: MOBY DICK, AHAB, UM LEITOR E O MURO
}

Ronie Von Martins* Cynthia Farina**

RESUMO: Este texto apresenta uma experiência de aprendizagem com uma obra literária e com ideias filosóficas. Ele é narrado por um Leitor, personagem fascinada pelo encontro com Moby Dick de Melville, que conta uma experiência de perda de sentido com o universo educativo, com o universo do ensinar e aprender. Para enfrentar tal experiência, ele busca aliar-se a alguns conceitos, especialmente, de Deleuze e Guattari. Entende, então, que o pensamento filosófico não dá apenas referências, mas o impulsiona também em direções não pensadas, não previstas por ele. Com personagens literários e filosóficos, ele vive e busca expressar uma experiência de aprendizagem: uma "aprendizagem do naufrágio". Entende que uma aprendizagem não se encerra na conquista de um saber, mas tem uma íntima relação com um desprender-se de si próprio.

Palavras-chave: Aprendizagem; Filosofias da Diferença; Literatura.

\section{THE WRECK LEARNING: MOBY DICK, AHAB, A READER AND THE WALL}

ABSTRACT: This paper presents a learning experience through a literary work and some philosophical ideas. It is narrated by a reader - a character fascinated by the encounter with Melville's Moby Dick - who tells the experience of loss of meaning with the educational universe and with the universe of teaching and learning. To face such an experience, he seeks to ally with some of Deleuze and Guattari's concepts. Thus he understands that philosophical thinking not only provides references, but also pushes him towards directions he himself had not even thought about. Along with literary and philosophical characters, he lives and seeks to express an experience of learning: 'learning from the wreck'. He realizes that learning does not end with the conquest of a piece of knowledge, but rather, it has an intimate relationship with the letting go of oneself.

Keywords: Learning; Philosophies of Difference; Literature.

* Pós-Graduado em Linguagens Verbais e Visuais e suas Tecnologias pelo Instituto Federal de Educação Tecnológica Sul-RioGrandense (IF-Sul) e em Literatura Brasileira Contemporânea pela Universidade Federal de Pelotas (UFPEL); Professor de Língua Portuguesa e Literatura da Rede Municipal e Estadual de Pedro Osório e Cerrito (RS). E-mail: ronieev@gmail.com

**Doutora em Educação pela Universidad de Barcelona; Coordenadora do GP Educação e Contemporaneidade: Experimentações com Arte e Filosofia (EXPERIMENTA); Professora do Instituto Federal de Educação Tecnológica Sul-RioGrandense (IF-Sul). E-mail: cynthiafarina@pelotas.ifsul.edu.br 


\section{Introdução}

Um Leitor busca conhecer uma experiência de encontro com obra literária. Escreve. Aproxima-se das filosofias da diferença para esse conhecimento, quando percebe que essas filosofias também guardam, em si, experiências que pensava existir apenas no universo da literatura. Experiências que mais inquietam do que apaziguam.

Este texto se escreve a partir de experiências com a literatura de Herman Melville, concretamente com Moby Dicke , e de experiências, principalmente, com a filosofia de Deleuze e Guattari, como também, de Foucault. Procura fazê-lo, acolhendo o movimento promovido no pensamento por essas ideias, quer dizer, buscando produzir algumas referências que permitam aprender desta experiência, deste momento, sem paralisálo. Dessa tentativa, o texto pratica e propõe a ideia de uma "aprendizagem do naufrágio".

Um Leitor emaranha-se no pensamento filosófico, assim como Ahab o fazia no corpo da baleia, alcançando lugares além de sua história, do livro e da própria literatura. Ahab se diluía, mesclando-se nas águas e seres desse mar de possibilidades, lambendo lascivamente todas as estruturas morais, sociais e políticas de sua época, sem nunca parar de escorrer pelos espaços do pensamento daqueles que com ele experimentavam o naufrágio do senso comum, da opinião, dos lugares-comuns, das ideiasfeitas, dos falsos problemas. O naufrágio do "eu". Onde há saber e poder, já nos dizia Foucault, há resistência, e isso interessa a este trabalho. Resistir através da e com a literatura, amarrado ao corpo de um pensamento nômade que não se encerra na simples conquista de um saber, mas que está sempre por começar; um saber que se desenvolve pelo meio e em seu fluxo, resiste e enfrenta os mecanismos de estratificação social, educacional, pedagógico.

É disso que Melville faz Ahab falar. É isso que Ahab vem a ser. Fluxo constante do movimento da vida, movimento que se desprende e retorna às forças marinhas, abissais e insondáveis do mar, de Moby Dick, da literatura, do enunciado, da proposição, do caos e do pensamento. Atravessando com seu corpo textual, através de naufrágios, lugares de uma "impossibilidade" contestada.

Ahab, Melville, Deleuze, Guattari nos ensinam que, para aprender, necessitamos aceitar os naufrágios. O Leitor que escreve este texto 
busca acolhê-los. Primeiro, acolher o naufrágio de um "eu", dessa criatura de um só e mesmo rosto que navega em generalidades vagas. Depois, busca acolher o naufrágio das formas de representação que o atracaram falsamente em um cais de certezas universais e o fizeram refém entre paredes de uma subjetividade amuralhada. As aprendizagens ensaiadas neste artigo se desenvolvem no cruzamento das experiências de um Leitor que "naufraga" em uma obra literária e a utiliza como instrumento de resistência à própria língua. Nesse afogar-se, ele emerge com os olhos vermelhos de esforço. Um Leitor que, emaranhado nas linhas da literatura, da leitura e da escrita, vale-se do pensamento de Deleuze e Guattari para dar sentido a uma experiência e torná-la aprendizagem. Este texto dá fé, recolhe e dá sentido a essa experiência de aprendizagem.

\section{A caça}

\section{A caça - Primeiro dia}

Afundava.

Até onde o respirar já não seria útil. Entre os destroços de possíveis, a caça do improvável.

Imenso o mar. Respirar a água, o sal.

Denso e enorme o muro. Insólito espaço de luta.

Erguíamos, todos, os arpões em brinde. Neles bebíamos o sangue de nossas próprias vidas.

E gritávamos ao firmamento. Éramos senhores do mar. Deuses. Demônios. Pacto de vinho.

Todos éramos não mais os mesmos, mas ele. Matilha. Um e vários lobos. Do mar. E os destinos se traçavam nas linhas que construíam a viagem.

Nossa busca, um muro.

\section{A caça - Segundo dia}

Era infinitamente mais branca que enorme.

Inversão do buraco negro devorador da matéria. Ponto branco. Ponto zero. Encontrar Moby Dick era encontrar o sem nome do oceano.

Um Pequod tentava dar sentido ao seu gesto, pensamento e vida. Oceano

Educação em Revista | Belo Horizonte | v.27 | n.02 | p.21-40 | ago. 2011 
sem texto.

Velocidades crespas. Um navegar pela baleia. Para a baleia.

Ideia-iglu. Ideia-barco-Pequod.

E pulávamos e girávamos em torno do dobrão de ouro. Matilha de lobos. Éramos todos um.

Ahab.

Afundar. Até onde o respirar já não seria útil.

\section{A caça - Terceiro dia}

Arpão forjado com sangue de pagãos. Linhas de cânhamo. Projéteis de vida e morte arremessados dos botes se oferecem à imensidão.

Entre dobras indefinidas, um homem lê. Delírio e captura. Preso, um gavião do mar. Lida que se desenrola. Afundando, naufragando. Para muito além do barco e da palavra sua.

Respirar.

\section{Mar aberto}

Assim como Ahab, um Leitor encontrava-se enrolado ao corpo da obra literária. Enrolado à Moby Dick de Melville. E, sem dúvida, naufragar era preciso. Era imperativo provar da morte singular de Ahab, experimentar seu desequilíbrio, sua força... e perecer. Mas não desfazer-se totalmente, senão morrer em um importante sentido. Morrer para aquilo que já não fosse criação e, por conseguinte, para aquilo que predispusesse a vida, a arte e a literatura a meros instrumentos de representação da experiência com o real. Tratava-se de uma morte ligada a um aprendizado.

A representação estabelecida pela razão clássica como forma de abordar nossa experiência conosco mesmos e com o mundo instituiu uma simbologia e a plantou em terrenos de pura estratificação ${ }^{2}$. Essa simbologia expressa um modo específico de conhecer a realidade, um modo que a representa, que conhece por meio dos símbolos da representação que reedita. ${ }^{3}$ Assim, a realidade se vê percebida e entendida através das regras e sistemas que a definem, tal como se apresentou no sistema dominante do pensamento ocidental. Deleuze e Guattari oferecem um pensamento filosófico capaz de abordar essas questões. Os autores evidenciam três gran-

Educação em Revista | Belo Horizonte | v.27 | n.02 | p.21-40 | ago. 2011 
des tipos de estratificação do pensamento atual: o organismo, a significância e a subjetivação, que impedem a abertura de brechas no saber preestabelecido, a abertura do corpo e tantas e várias conexões com a vida. ${ }^{4} \mathrm{O}$ Leitor necessita o máximo possível, desaprender os estratos da representação que o ligavam a um tipo de leitura, que o ligavam mais aos símbolos que representam uma leitura que à experiência de leitura de uma obra como Moby Dick, de Melville, ou da própria filosofia de Deleuze e Guattari.

A força da literatura. A intensidade da filosofia... "O que define o pensamento, as três grandes formas do pensamento, a arte, a ciência e a filosofia, é sempre enfrentar o caos, traçar um plano, esboçar um plano sobre o caos". Seria com essa forma de pensar que o Leitor começava a se avizinhar. E Deleuze e Guattari são categóricos ao afastar a ideia do pensar da prática da opinião. ${ }^{6} \mathrm{~A}$ opinião, para os autores, é "vontade de maioria", vontade do mesmo, em desatenção àquilo que pode forçar o pensamento a pensar e não apenas a reproduzir opiniões prontas, em circulação nos meios de comunicação, como também no meio literário e filosófico instituídos. Para o Leitor, não se tratava de realizar uma leitura que representasse essa vontade na experiência com Moby Dick. O pensamento teria mais a ver com um mergulho nas forças contidas no oceano de Moby Dick, na obra de literatura feita desse enfrentamento com o caos. Não um mero "abandonar-se", mas possibilitar, através desse mergulho, maneiras de resistir e ou se beneficiar dele. Arte, ciência e filosofia têm, para os filósofos, maneiras específicas de se enfrentar ao caótico, a essa dimensão da realidade constituída do movimento contínuo de forças vivas. Extraem dele uma qualidade específica do pensar. Traçar planos estéticos, de funções, filosóficos sobre o caos tem a ver com oferecer novas possibilidades de se habitar a vida, na medida em que tentamos abandonar as opiniões que a cercam e cerceiam nosso próprio pensamento.

Um amém à organização do corpo e não à vida; um amém à forma preestabelecida, às formas instituídas "pela vontade de maioria”. É contra isso que Ahab também investe. Ahab promove uma morte. Um suicídio do próprio corpo organizado, do organismo estratificado, da significação do vivido. Naufrágio que o levará a um outro espaço, outra forma de vida. Uma brecha? Ao falar de Ahab, é importante lembrarmonos do conceito de personagens originais tratado no célebre artigo intitulado "Bartleby o la fórmula", em que Deleuze trata de ambas as personagens, 
cada uma agindo a seu modo diante da imposição paternalista e estatal da sociedade. Seria uma brecha a fórmula de Bartleby? "Bartleby deja de copiar, es decir, de reproducir palabras; inaugura una zona de indeterminación en la cual las palabras ya no se distinguen, abre un vacío en el lenguaje. Pero, al mismo tiempo, desactiva aquellos actos de habla mediante los cuales un jefe puede dar órdenes, un amigo bienintencionado puede hacer preguntas o un hombre de fe puede prometer."'

Moby Dick, de Herman Melville, possui uma gama de sentidos inclassificáveis. Entretanto, a questão do morrer e do renascer aparece por toda a obra. Um caixão que, antes de conduzir para a morte, da morte, reconduz a vida ao mundo. No entanto, não se furta de permitir, da beirada do precipício, a visão do vórtice: a voragem assustadora e sensual das forças do caos. Tashtego ${ }^{10}$, que afunda para a morte dentro da cabeça de uma baleia e que renasce, sobrevive, partejado por Quiqueg no capítulo "A cisterna e os baldes". ${ }^{11}$ O próprio Quiqueg que adoecendo, prepara seu caixão e, quando se acredita ser certa sua morte, simplesmente levanta e continua. Fato relatado no capítulo "CX: Quiqueg em seu féretro" de Moby Dick. O próprio Ahab, ao morrer como homem, devém baleia. Assim como Ismael, antes de afundar no vórtice do Pequod, é salvo pelo caixão de Quiqueg... Ahab, Ismael, Tashtego, Quiqueg. Não esqueçamos Pip, ou Semente-de-Maçã, que, ao ser abandonado no mar em uma caçada à baleia, retorna encharcado de uma profética loucura que sensibiliza até mesmo Ahab. Todos abandonam seus corpos, têm a existência desorganizada, experiência de perda extrema de sentido do real, porém todos retornam à vida. Todos se banham na morte. Todos naufragam. Esse naufrágio sinaliza a fórmula, pois "desconecta las palabras de las cosas, pero también los actos de las palabras: priva al lenguaje de toda referencia"12. Todos renascem. Ressuscitam. Um, na cabeça da baleia, afunda. O outro, para viver, tem que dar conta de sua própria morte e enfrentar o próprio caixão. Pip ressuscita nos braços da loucura; Ismael volta do vórtice de morte do navio; Ahab devém Moby Dick. A caça no mar exige essas mutações. A experiência, a travessia pelos espaços do caos, o contato com as forças de vida e morte determinam e possibilitam novas criaturas - novos corpos e novas formas de perceber espaços, antes, improváveis. Homens que se candidatam a enfrentar a linha divisória que separa aquilo que entendemos como vida e o flash poderoso de ser alcançado por forças caóticas. Ser Ahab, mas também Ismael, ser Bartleby, mas também o advogado. 
São várias as passagens em que Herman Melville lida com os valores de vida e morte, valores que são capazes de sobressaltar de forma singular a existência, tensionando, desmoronando essa forma de vida a que insistimos em nos agarrar, "guarda-sol que nos protege do caos"13, já diriam Deleuze e Guatarri. A tripulação do singular navio Pequod decide, guiada pela fúria de Ahab, abrir definitivamente uma brecha no paredão que os reduz. No entanto, não é através da dicotomia vida-morte, mortevida, que Melville conduz seu texto e seu navio. Pelo contrário, tanto a vida quanto a morte fazem parte da mesma linha de cânhamo arremessada dos botes baleeiros. Fazem parte da própria experiência de aprendizagem, do saber que cada um tem que adquirir para enfrentar o muro. Há em Moby Dick um interessante diálogo entre Ahab e Starbuck, um dos comandantes do barco, que evidencia claramente a condição de muro, parede, em que a baleia se investe para Ahab:

Todos os objetos visíveis, homem, não são mais do que máscaras de papelão. Mas em cada acontecimento - o ato vivo, o efeito indubitável - há sempre algo desconhecido, mas ainda assim racional que projeta os seus contornos detrás da máscara. Como pode o prisioneiro alcançar o lado de fora, se não arremessando-se através da parede? Para mim o cachalote branco é a parede. $^{14}$

A baleia Moby Dick personifica, para Ahab, todos os obstáculos que o impedem de ser o que ele acredita que poderia ser. O cetáceo se torna um muro, uma parede que deve ser encontrada e destruída para que ele, Ahab, consiga finalmente ultrapassar os limites que sua existência lhe infringe. Todavia, Moby Dick não é só o muro. A baleia gigante também está conectada com o próprio caos, com o fluxo caótico. Ao enfrentar a baleia-muro, Ahab é absorvido pelas forças alucinantes desse caos. Ahab acaba tornando-se fluxo dessa força que o acolhe. Ahab se enfrenta numa experiência de aprendizagem?

Vida e morte definem a visão de cada personagem agenciada ao dobrão de ouro ${ }^{15}$. Olho do caos cravado no mastro central do navio. É através da proximidade entre vida e morte que se definem as transformações sofridas pelas personagens e os agenciamentos ${ }^{16}$ decorrentes disso. Para Espinosa de Deleuze, todas as coisas do mundo estão em relação umas com as outras e, portanto, devem ser pensadas por meio de composições ${ }^{17}$. Logicamente, não podemos esperar que todos os agenciamentos 
devam ser bons ou possíveis. O que interessa é pensar a existência, a vida, em termos de composição e decomposição. Há composição alegre com o outro quando nossa potência de agir é aumentada; há decomposição, quando, nesses agenciamentos, nosso poder de ação é diminuído. Para Espinosa em Deleuze, serão os encontros que determinarão o rumo que daremos à vida. Vamo-nos, portanto, com bons e maus encontros e nossos caminhos vão sendo configurados pela forma como somos afetados por esses encontros e agenciamentos, a partir deles. Talvez uma aprendizagem alegre tenha a ver com apostar pelas composições nas quais nossa potência de agir seja aumentada e não o contrário.

Melville trança suas tramas com a corda de cânhamo através do encontro e agenciamento entre Ismael e Ahab, entre vida e morte, e faz surgir para cada personagem um "outro mundo do mundo"18, como dizia Blanchot. Para o Leitor, era importante essa concepção que Blanchot trazia, pois, assim como ele, percebia a literatura não como uma forma de representar o mundo, o real do mundo, mas sim como um caminho, um meio de possibilitar à literatura a criação de outro mundo, um outro real. O real da própria literatura. Ahab e Ismael são palavras, são literatura e, ao mesmo tempo, estão vivos "realmente". Vivem pela arte criadora do texto literário, dão-nos a ler um "outro mundo do mundo". ${ }^{19}$

Ironicamente, Melville une dois personagens que buscam coisas aparentemente opostas. Ismael, o narrador da história, busca na água a vida, uma linha de fug $a^{20}$, uma brecha para respirar um possível. Leiamos, novamente, Deleuze e Guattari. Os filósofos concebem a existência como uma geografia cheia de linhas que a atravessam e delimitam. Talvez possamos dizer que as linhas de fuga são os caminhos que se abrem em uma experiência para buscar novas formas de dar conta dessa existência. Não são fugas da vida ou da existência, mas vias para nos posicionarmos de outras maneiras nos espaços ainda não ocupados, para resistirmos às linhas de estratificação que delimitam nossa experiência. Ismael busca vida, e é na visão e na experiência da morte - o fim da tripulação, salvamento pelo caixão - que adquire consciência desta. Ismael aprende um grau de potência vital. Ahab, por outro lado, busca na morte a passagem para outra forma de vida, engendra todos os passos para isso, e é na morte que adquire, finalmente, vida. Ahab aprende no naufrágio o enfrentamento e a dissipação do muro. Ismael permanece na borda do caos e desse agenciamento produzirá linhas de fuga. Ahab não se contenta em obser- 
var o vórtice caótico, ele precisa encharcar-se com essa energia, ser um fluxo dela. Ahab remete-nos, aqui, a Antonin Artaud. ${ }^{21}$

Nessa experiência de perda de sentido e naufrágio, o Leitor, além de Deleuze e Guattari, de Melville e Ahab, também se permite encontros e agenciamentos com outros náufragos, e Artaud é aquele que mais profundamente afundou ${ }^{22}$. E o Leitor-escritor abraça seu texto ao corpo desorganizado deste como Ismael ao caixão de Queequeg, ou mesmo Ahab ao corpo da baleia branca.

Artaud foi Ahab. Ahab foi Antonin Artaud. Ambos negaram de forma veemente as estratificações instituídas pela sociedade para suas existências, encontrando na loucura e no naufrágio uma forma de se transformar num "outro", "vivo morto", "morto sempre vivo". ${ }^{23}$ Artaud se transforma numa personagem estética, já não é mais um "homem", "a tragédia encenada já não basta", a representação não é suficiente, ele precisa ir além; Ahab enfrentando a tragédia, tornando-se ela mesma. Ahab metamorfoseando-se em baleia, transpondo para sua vida a tragédia. Eles criaram "O outro de todos os mundos"24.

Ahab e Artaud compõem uma visão para o Leitor. Ele os vê máquinas de guerra ${ }^{25}$. Ele os vê, com Deleuze e Guattari, forças oriundas do próprio caos e que abrem caminho para voltarem a ele. E com essa visão o Leitor aprendia. Ele, assim como Ismael, aprendia o limite da entrega ao caótico que vive na obra de criação escrita com essas forças. Aprendia no encontro com as forças que vivem em uma obra literária, aprendia que há que se levar uma porção de estrato para a viagem. Os filósofos já o advertiram: há que se guardar uma porção de organismo, de significação e de identidade no confronto com o $\operatorname{caos}^{26}$. Prudência, dizem eles.

Ser Ismael quando se pretendia Ahab. O Leitor estava amarrado às linhas. Amarrado a Ismael e Ahab.

\section{A palavra e o mar}

Escrever. Já não bastava ler. Não bastava a fruição do texto que o afogava, que o fazia naufragar na textura literária. Era preciso aventurar-se, arriscar-se à palavra. Era preciso fazer-se máquina de escrita. E Ahab era a palavra mágica. Ahab. Força, potência que o impelia e o invadia de tantas e estranhas sensações. Ahab era a condição necessária para 
seu gesto. Ahab se tornava devir que o aproximaria perigosamente do experimentar literário. Mas Ismael era quem o mantinha na borda do precipício textual. Prudência, uma voz insistia.

O Leitor necessitava, agora, aprender a se soltar dos estratos agarrados à prática da escrita. E, para isso, devia observar os barcos. Via os barcos que singravam sem sangrar, calmos e dóceis. Docilidade de linhas que não se cruzam. Boiar. Distantes da possibilidade impetuosa do espaço liso. ${ }^{27}$

Pensava no grande corpo da Educação que levantava velas impulsionado pelo vento dos discursos estatais, e que continuava triunfante sua viagem estratificando o próprio gesto viajante. Além dos ratos que leva na escuridão e umidade do porão, levava também razões germinadas em terrenos estriados, normatizados, cristalizados. O Leitor pensava em suas relações com esse corpo, em suas relações com o gesto da ordem, da disciplina, do re-conhecimento e da identidade, e buscava formas de entender as flexibilizações a que os corpos eram chamados a configurar:

O que se invoca a flexibilizar é uma economia e uma política dos processos de formação, cujo acento na improvisação se refere à capacidade de inserir-se em um modelo subjetivo necessário aos modos de produção e consumo das relações, da experiência mesma na contemporaneidade. Por isso, trata-se de gerar uma atenção capaz de discernir, no conjunto dos discursos sobre as relações atuais, os que avalizam, incorporam, ignoram ou escamoteiam os modos homegeneizantes de formação do subjetivo. Trata-se segundo Deleuze e Guattari, de tentar cartografar esses movimentos, de problematizálos, para tornar evidentes os modos de percorrer e saber a experiência coletiva que gera modos de vida específicos. ${ }^{28}$

O Leitor tentava cartografar os movimentos que o configuravam, buscava entender no próprio movimento de seu pensar aquelas vozes, aquelas linhas que tanto o tornavam Ismael e Ahab, pois pensava em si mesmo como funcionário. Pensava: Ahab existe em mim, mas existe também um professor funcionário público soterrado em seus pequenos óculos, navegando na aura de seu eu, sem velocidade ou ímpeto. Um arranhar lento e irritante. Unhas grandes que se afiam em didatismos, ideologias, tendências, que não se atrevem ao risco.

O Leitor precisava se ater mais à formação de suas formas de pensar, procurava estar atento à forma de fazer as ideias tomarem o mundo: suas intensidades e densidades. Uma atenção era necessária. As 
ideias falavam e suas vozes deviam ser escutadas, seu movimento sinuoso devia ser observado. Atenção. Elas deviam estar realmente agenciadas aos acontecimentos que lhes proporcionavam vida.

Portanto, o Leitor precisava estar à espreita em relação ao terreno da literatura e suas implicações possíveis no ponto onde a literatura, sua vida e forma de pensar se conectavam. Buscava na relação da literatura e da vida, um conhecimento que se indagava a partir dessa atenção às forças que dobravam e reforçavam o professor funcionário público, ou Ahab, ou Ismael. Buscava uma atenção às forças que dobravam a subjetividade e a configuravam.

Há que se combater o burocrata da palavra lida, da palavra escrita, das formas educadas que vivem em nós. Regras e dogmas. Leis e normas. Dicotomias. Reducionismos. Estratégias de peixinhos no aquário. Quadro-negro repleto de clichês. Há que se combater as imagens da representação que destinam o navio ao aquário.

No entanto, entre todos os seguros e possíveis barcos que singram a água, Ele, o Leitor-escritor, escolhe o que sangra. Pequod, a nau do capitão Ahab, o navio literário que se arremessa na boca e pela boca de Moby Dick, garganta do caos. Dentro desse vasto oceano onde cada um, indiferente à experiência que o atravessa, busca apenas a apropriação do conhecimento - extensão e quantidade de cultura e informação -, o Leitor-escritor entendia que, pela intimidade com a leitura e, por conseguinte, pela construção de uma escrita e de um estilo que se avizinhasse de um produzir literário, teria a oportunidade de fazer navegar sua singular embarcação pelo ambiente acadêmico. Uma escrita própria e multiforme que fosse capaz de articular outras e diferentes formas expressivas de aprendizado.

Os outros barcos que Melville coloca em sua obra, o Delight, Samuel Enderby, Bachelor, entre outros, apenas flutuam na água, e dela pouco buscam. Colhem o que podem com suas redes. Pequenas redezinhas, malhas que acreditam captar e selecionar todas as forças do elemento vital. Mas ele aprendeu com a experiência do naufrágio. Experiência que não se aprende de uma vez por todas. Volta-se a ela. Sangrar o organismo, as identidades, os rostos, e encontrar o sem-nome, o sem-sentido. Permitir que o Estado em nós continuasse seu trajeto traçado e determinado pelas estrias que lhe conformam? Ele quer não o fundo, não o niilismo barato e fácil. Ele quer lançar um olhar à espreita. Necessita um 
pensamento que consiga, como diria Foucault, perceber os mecanismos de rarefaça $\tilde{o}^{29}$ que erigem os grandes e pequenos muros que nos resumem e nos reduzem ao que o discurso estatal deseja, para daí, com olhos tingidos da vida e de caos, regressar, traçar um plano sobre o caos, construir uma nave-máquina capaz não de negar o caótico, mas de expressar essa viagem: capaz de expressar uma aprendizagem dessa experiência.

Surpreende também toda a complexa e cada vez mais sofisticada rede de regulação e ordenamento do subjetivo, o sofisticado funcionamento do coletivo que assume o variável para codificá-lo, que flexibiliza modelos de atuação para garantir perfis adaptáveis aos modelos de mercado. A esses modos de produção do contemporâneo que promovem a flexibilização da subjetividade para garantir a produção do mesmo se dirige a crítica de Foucault e Deleuze. Seu pensamento ataca a homogeneização da percepção e do saber que constituem as formas de vida. ${ }^{30}$

Retornar eternamente à diferença dos movimentos e repousos que nos constituem. Aprender.

Ir além. Com Ahab. Para Ahab e o naufrágio. Naufragar as possibilidades banais de qualquer discurso, de qualquer saber da opinião, do re-conhecimento instituído, da aprendizagem. Buscar o corpo de Moby Dick. Amarrar-se e emaranhar-se nas "impossibilidades" advindas desse ato... e sobreviver ao "possível". Para além ou aquém dele.

Proporcionar-nos um navio frágil à força das vagas, descobrir, através das experiências do texto e da vida, novas formas de composição com um pensamento do naufrágio contido na experiência da leitura e da escrita, na experiência filosófica, no que há de aprendizagem com essas experiências. Decompor-se. Indispor-se. Compor-se outro. Ser o "já-nãoser" e, ainda assim, não ser o que "seria" esperado que fosse, estar no meio e, no meio, estar à espreita. Cutucando o muro, abrindo buracos, resistindo ao rosto estatal, à identidade moral, ao professor funcionário público. O convite vem de Ahab: Vamos à baleia! O convite vem da baleia! Vamos ao mar!

Só um singular Pequod ouve o apelo. Somente a vetusta embarcação com sua singular tripulação ouve o apelo.

O Leitor-escritor via que, na sua tarefa de escrever, não bastava construir uma frase e lapidá-la até fazê-la sedutora. Se fosse apenas isso, ele estaria traindo Ahab. Ahab não é polidez, mas estilo ${ }^{31}$. Ahab deveria ser 
o próprio texto, ir além da personagem. Além do livro. O arpão do capitão de Herman Melville tinha de ser presença no texto. O som desconfortante de sua perna de marfim irritando o "senso comum", a opinião.

Deleuze e Guattari, no capítulo "Do caos ao cérebro" de O que é a Filosofia?, tecem interessante parágrafo sobre o que seria esse "senso comum" ou os "clichês" da opinião:

O pintor não pinta sobre uma tela virgem, nem o escritor escreve sobre uma página branca, mas a página ou a tela estão já de tal maneira cobertas de clichês preexistentes, preestabelecidos, que é preciso de início apagar, limpar, laminar, mesmo estraçalhar para fazer passar uma corrente de ar, saída do caos, que nos traga a visão. ${ }^{32}$

Ahab era um confronto no texto sobre a aprendizagem do Leitor, sobre a relação dele com algumas formas desses "clichês". Aríete contra os muros das lamentações. Devir que levasse às brechas nas paredes da subjetividade que já não percebe as potências do dito "impossível". Ahab. A literatura tem esse poder, a arte tem esse poder. E a filosofia também. Pretensão. Ismael sorria do outro lado das palavras. Como produzir uma escrita com essa ordem de experiências, sem se desentender da educação, de seu peso, do sentido que a conduz? Experimentar, dizia Ismael. Experimenta. E Ahab gritava: "Continuai remando! Sim, com força agora... vamos nos aproximar dele. O leme! Tomai o leme! Deixai-me passar!"'33.

Morte-vida? Vida-morte-ressurreição? Espaço de impossível que convida a um mergulho? É Melville mesmo que sugere o mergulho como forma de buscar novas formas de dar sentido à vida: “... olhai, aí vêm multidões, dirigindo-se para a água e aparentemente procurando a oportunidade de um mergulho!" ${ }^{34}$.

Uma escrita das forças que deseja Ahab, mas que não impede de estar junto a Ismael. Pode ser Ismael. Não se trata de exclusões, mas de composições. Compor com Artaud e Ismael, com a literatura e a educação, com educação e filosofia. Pensar Deleuze, Melville e Guattari, também Blanchot e Foucault. Compor leitura e escrita, caos e aprendizagem, experiência e experimentação, estratificação e nomadismo, literatura e ciência da educação.

Naufragado. Afogado. Corpo que se permitia o contato e o atravessamento de forças várias. Intimidade e paixão. Contato. Vulnerabili- 
zado o corpo e exposto ao risco. Era dessa forma que o Leitor-escritor buscava aproximar-se da literatura, filosofia e da Educação. Expor seu corpo textual qual o navio Pequod ao risco e ao naufrágio. Não mais como um sujeito cartesiano. Seguro em suas certezas. Indiferente e inatingível pelo singular canto das sereias como Ulisses. Mas homem que se banha na água e no sal pelo qual navega. Composição de carne-mar-caos. E era dessa forma que tencionava navegar, pensar e fazer pensar nas instituições acadêmicas e educacionais. Não via sentido mais na mera apropriação de saberes, da aquisição de conhecimento. Isso não mais lhe transformava ou fazia sentido, mas percebia que, através do contágio, dos encontros e acontecimentos, a cada vez que "sobrevivia" aos seus naufrágios e retornava com os olhos vermelhos, algo se dava. Algo acontecia. Co-habitava os espaços. Mesclava-se e possibilitava outras e novas formas de se relacionar com o saber.

Escrever é um fluxo entre outros, sem nenhum privilégio em relação aos demais, e que entra em relações de corrente, contracorrente, de redemoinhos com outros fluxos, fluxos de merda, de esperma, de fala, de ação, de erotismo, de dinheiro, de política, etc. ${ }^{35}$

O Leitor, afetado pela força do que vive no texto que o captura e arremessa no caótico, pode fazer-se um aprendiz das intensidades? Não há nenhuma segurança disso. A prática com a textura intensiva de uma obra literária necessita ser feita a cada vez. Não há garantias. A aprendizagem se dá a cada vez. Naufragar para aprender. Aprender e naufragar, na leitura, na escrita, no pensar. Estar à espreita e praticar composições. Inclinar-se pelas alegres. Experimentar no mar, contra o muro. Aprender um naufrágio. 


\section{REFERÊNCIAS}

DELEUZE, Gilles.; AGAMBEN, Giorgio; PARDO, José Luis. Preferiría no Hacerlo. Bartleby el escribiente de Herman Melville, seguido de tres ensayos sobre Bartleby de Gilles Deleuze, Giorgio Agamben, José Luis Pardo. Valencia: Pre-textos. 2001

DELEUZE, Gilles. Crítica e Clínica. Trad. Peter Pál Perbart. São Paulo: Editora 34, 1997. DELEUZE, Gilles. Conversações. Trad. Peter Pál Perbart. São Paulo: Editora 34, 1992.

DELEUZE, Gilles. O abecedário de Gilles Deleuze. Disponível em <http://www.ufrgs.br/faced/tomaz/abc3.htm >. Acesso em 18.9.2007.

DELEUZE, Gilles. Spinoza: filosofía práctica. Buenos Aires: Tusquets, 2006.

DELEUZE, Gilles; GUATTARI, Félix. Mil Platôs: Capitalismo e Esquizofrenia v. 1. Trad. Aurélio Guerra Neto e Célia Pinto Costa. São Paulo: Editora 34, 1995.

DELEUZE, Gilles; GUATTARI, Félix. Mil Platôs: Capitalismo e Esquizofrenia v. 3. Trad. Aurélio Guerra Neto, Ana Lúcia d’Oliveira, Lúcia Claudia Leão e Suely Rolnik. São Paulo: Editora 34, 1996.

DELEUZE, Gilles; GUATTARI, Félix. Mil Platôs: Capitalismo e Esquizofrenia v. 5. Trad. Peter Pál Pelbart e Janice Caiafa. São Paulo: Editora 34, 1997.

DELEUZE, Gilles; GUATTARI, Félix. O que é a Filosofia? Trad. Bento Prado Jr. e Alberto Alonso Muños. São Paulo: Editora 34, 1997.

ESPINOSA, Baruch de. Da Servidão Humana ou das Forças das Afecções. São Paulo: Nova Cultural, 1997. (Coleção Os Pensadores)

FARINA, Cynthia. Artifícios Perros. Cartografia de um Dispositivo de Formação. 29a REUNIÃO DA ASSOCIAÇÃO NACIONAL DE PÓS-GRADUAÇÃO E PESQUISA EM EDUCAÇÃO - ANPED, Anais... GE: Educação e Arte/ nº 01.

FOUCAULT, Michel. A ordem do discurso. Trad. Laura Fraga de Almeida Sampaio. São Paulo: Perspectiva, 2005.

GIROTTO, Nara Lúcia. Blanchot, Foucault e Deleuze: Convergências entre a palavra literária, a experiência do Fora e o impensado. Disponível em

<http://www.unisc.br/cursos/pos_graduacao/mestrado/letras/anais_2coloquio/convergencias_palavra_literaria.pdf $>$. Acesso em 27.2.08.

MELVILLE, Herman. Moby Dick. Trad. Berenice Xavier. Rio de Janeiro: Ediouro, 2001. MELVILLE, Herman. Moby Dick. Trad. Péricles Eugênio da Silva Ramos. São Paulo: Nova Cultural, 2003.

SCHOPKE, Regina. Por uma filosofia da diferença: Gilles Deleuze, o pensador nômade. Contraponto. São Paulo: Edusp, 2004.

WILLER, Cláudio. Escritos de Antonin Artaud. Porto Alegre: L\&PM, 1983. (Coleção Rebeldes \& Malditos v. 5) 
1 Publicado em 1851, a obra literária Moby Dick foi o livro mais importante de Herman Melville, que nasceu em Nova Iorque, em primeiro de agosto de 1819 e faleceu em 28 de setembro de 1891, quase na obscuridade como escritor. Moby Dick conta a história de Ahab, um obcecado capitão, que, tripulando o Pequod, um singular baleeiro, e comandando uma tripulação ainda mais singular, caça a baleia branca Moby Dick. A história é narrada por Ismael, único sobrevivente da tripulação no confronto com a baleia. Neste trabalho, foram usadas as duas traduções mais conhecidas da obra, uma de Péricles Eugênio da Silva Ramos e outra de Berenice Xavier.

2 "Os estratos eram Camadas, Cintas. Consistiam em formar matérias, aprisionar intensidades ou fixar singularidades em sistemas de ressonância e redundância, construir moléculas maiores ou menores no corpo da terra e incluir essas moléculas em conjuntos molares." DELEUZE, Gilles; GUATTARI, Félix. Mil Platôs: Capitalismo e Esquizofrenia v.1. São Paulo: Editora 34, 1995. p. 54.

3 "Na realidade, os conceitos e toda a gama de símbolos que utilizamos na representação não podem dar conta do sentido mais interno, do que há de mais singular e que não pode ser expresso pela linguagem, será preciso inventar novos conceitos para fazer passar o que há de fluído e cambiante nos seres." SCHÖPKE, Regina. Por uma filosofia da diferença: Gilles Deleuze, o pensador nômade. Rio de Janeiro. Contraponto. São Paulo: Edusp, 2004. p. 102.

4 “Você será organizado, você será um organismo, articulará seu corpo - senão você será um depravado. Você será significante e significado, intérprete e interpretado - senão será desviante, você será sujeito e, como tal, fixado, sujeito de enunciação rebatido sobre um sujeito de enunciado - senão você será apenas um vagabundo." DELEUZE, Gilles; GUATTARI, Félix. Mil Platôs: Capitalismo e Esquizofrenia v. 3. São Paulo: Editora 34, 1997. p. 22.

5 DELEUZE, Gilles; GUATTARI, Félix. O que é a Filosofia? Rio de Janeiro: Editora 34, 1997. p. 253.

6 Sobre a ideia de "opinião", ver página 104, capítulo "Os personagens Conceituais”, da obra $O$ que é a Filosofia?, de Deleuze e Guattari. A ideia de uma oposição do pensar e do ato de opinar se estende por toda a obra.

7 DELEUZE, Gilles; GUATTARI, Félix. O que é a Filosofia? Rio de Janeiro: Editora 34, 1997. p. 190.

8 “define-se o caos menos por sua desordem que pela velocidade infinita com o qual se dissipa toda forma que nele se esboça. É um vazio que não é um nada, mas um virtual, contendo todas as partículas possíveis e suscitando todas as formas possíveis que surgem para desaparecer logo em seguida, sem consistência nem referência, sem conseqüência.” DELEUZE, Gilles; GUATARRI, Félix. O que é a Filosofia? São Paulo. Editora 34. 1992. p. 153.

9 DELEUZE, Gilles. Bartleby o la fórmula. In: DELEUZE, G.; AGAMBEN, G.; PARDO, J. L. Preferiría no Hacerlo. Bartleby el escribiente de Herman Melville, seguido 
de tres ensayos sobre Bartleby de Gilles Deleuze, Giorgio Agamben, José Luis Pardo. Valencia: Pre-textos. p. 67.

10 Tashtego, Quiqueg e Dagu são três personagens pagãos do baleeiro Pequod, arpoadores de Ahab que emprestam seu sangue para o capitão temperar um arpão especial para matar Moby Dick.

11 MELVILLE, Herman. Moby Dick. Trad. Péricles Eugênio da Silva Ramos. São Paulo: Nova Cultural, 2003. p. 328.

12 MELVILLE, Herman. Moby Dick. Trad. Péricles Eugênio da Silva Ramos. São Paulo: Nova Cultural, 2003. p. 67.

13 Cf. DELEUZE, Gilles; GUATTARI, Félix. O que é a Filosofia?, p. 260.

14 MELVILLE, Herman. Moby Dick. Trad. Berenice Xavier. Rio de Janeiro: Ediouro, 2001. p. 141.

15 O dobrão era uma moeda de ouro do Equador, mais especificamente de Quito, pregada ritualisticamente por Ahab no mastro do navio Pequod e prometido ao marinheiro que primeiro avistasse a grande baleia branca.

16 "Denominaremos agenciamento todo conjunto de singularidades e de traços extraídos do fluxo - selecionados, organizados, estratificados - de maneira a convergir (consistência) artificialmente e naturalmente: um agenciamento, nesse sentido, é uma verdadeira invenção." DELEUZE, Gilles; GUATTARI, Félix. Mil Platôs: Capitalismo e Esquizofrenia v. 5. São Paulo: Editora 34, 1997. p. 88.

17 DELEUZE, Gilles. Spinoza: filosofía práctica. Buenos Aires: Tusquets, 2006.

18 GIROTTO, Nara Lúcia. Blanchot, Foucault e Deleuze: Convergências entre a palavra literária, a experiência do Fora e o impensado. Disponível em

$<$ http://www.unisc.br/cursos/pos_graduacao/mestrado/letras/anais_2coloquio/convergencias_palavra_literaria.pdf $>$. Acessado em 27/02/08.

19 "O aparecimento da linguagem ficcional exige a destruição, a negação da palavra, àquela que estabelece a ligação entre o receptor e o objeto evocado pelo nome (palavra). Um direito à morte, um assassinato diferido, para usar as palavras de Blanchot, que provoca uma tranformação radical da palavra, isto é, desaparecimento das suas funções de representar o objeto para as funções de criar, evocar uma realidade constituída a partir da (ir)realidade da coisa à realidade da linguagem." GIROTTO, Nara Lúcia. Blanchot, Foucault e Deleuze: Convergências entre a palavra literária, a experiência do Fora e o impensado. Disponível em

<http://www.unisc.br/cursos/pos_graduacao/mestrado/letras/anais_2coloquio/convergencias_palavra_literaria.pdf $>$. Acessado em 27/02/08.

20 Sobre o conceito de linhas de fuga, ver o capítulo Rizoma de DELEUZE, Gilles; GUATTARI, Félix. Mil Platôs: Capitalismo e Esquizofrenia v. 1, p. 11.

21 Quem sou eu?/ De onde venho?/ Sou Antonin Artaud/ e basta que eu o diga/ Como só eu o sei dizer/ e imediatamente/ hão de ver meu corpo/ atual, / voar em pedaços/ e se juntar/ sob dez mil aspectos/ diversos/ Um novo corpo/ no qual nunca mais/poderão esquecer. / Eu Antonin Artaud, sou meu filho,/ meu pai/ minha mãe,/ e 
eu mesmo./Eu represento Antonin Artaud!./ Estou sempre morto./Mas um vivo morto,/Um morto vivo./Sou um morto/Sempre vivo./A tragédia em cena já não me basta./ Quero transportá-la para minha vida./ Eu represento totalmente a minha vida./ Onde as pessoas procuram criar obras/ de arte, eu pretendo mostrar o meu/ espírito./ Não concebo uma obra de arte/ dissociada da vida/ Eu, o senhor Antonin Artaud,/ nascido em Marseille/ no dia 4 de setembro de 1896,/ eu sou Satã e eu sou Deus,/ e pouco me importa a Virgem Maria. ARTAUD, Antonin. Para acabar com o julgamento de Deus. In: WILLER, Cláudio. Escritos de Antonin Artand. Porto Alegre: L\&PM, 1983. p. 146. (Col. Rebeldes \& Malditos v.5.)

22 “Antonin Marie-Joseph Artaud. 'Maldito', marginalizado e incompreendido enquanto viveu, encarnação máxima do gênio romântico, da imagem do artista iluminado e louco, Artaud passou a ser reconhecido depois da sua morte como um dos mais marcantes e inovadores criadores do nosso século. Tudo o que, aos olhos dos seus contemporâneos, pareceu mero delírio e sintoma de loucura, agora é referência obrigatória para as mais avançadas correntes de pensamento crítico e criação artística nas suas várias manifestações: teatro, arte de vanguarda e criações experimentais, manifestações coletivas e espontâneas, poesia, lingüística e semiologia, psicanálise e antipsiquiatria, cultura e contracultura. WILLER, Cláudio. Escritos de Antonin Artaud. Porto Alegre: L\&PM, 1983. p. 7. (Col. Rebeldes \& Malditos v.5.)

23 Ibid., p. 146.

24 GIROTTO, Nara Lúcia. Blanchot, Foucault e Deleuze: Convergências entre a palavra literária, a experiência do Fora e o impensado. Disponível em

$<$ http://www.unisc.br/cursos/pos_graduacao/mestrado/letras/anais_2coloquio/convergencias_palavra_literaria.pdf $>$. Acessado em 27/02/08.

25 Deleuze e Guattari denominam Máquina de Guerra as forças exteriores ao Estado, ao instituído e contra ele. "É que a exterioridade da máquina de guerra em relação ao aparelho de Estado revela-se por toda parte, mas continua sendo difícil de pensar. Não basta afirmar que a máquina de guerra é exterior ao aparelho, é preciso chegar a pensar a máquina de guerra como sendo ela mesma uma pura forma de exterioridade, ao passo que o aparelho de Estado constitui a forma de interioridade que tomamos habitualmente por modelo, ou segundo a qual temos o hábito de pensar." DELEUZE, Gilles; GUATTARI, Félix. Mil Platôs: Capitalismo e Esquizofrenia v. 5, p. 15.

26 Cf. DELEUZE, Gilles; GUATTARI, Félix. Mil Platôs: Capitalismo e Esquizofrenia v. 5, p. 22. "Desfazer o organismo nunca foi matar-se, mas abrir o corpo a conexões que supõem todo um agenciamento, circuitos, conjunções, superposições e limiares, passagens e distribuições de intensidade, territórios e desterritorializações medidas à maneira de um agrimensor."

27 “O espaço sedentário é estriado por muros, cercados e caminhos entre os cercados, enquanto o espaço nômade é liso, marcado apenas por 'traços' que se apagam e se deslocam com o trajeto.” DELEUZE, Gilles; GUATTARI, Félix. Mil Platôs: Capitalismo e Esquizofrenia v. 5, p. 52.

28 FARINA, Cynthia. Artifícios Perros. Cartografia de um dispositivo de formação. 29a REUNIÃO DA ASSOCIAÇÃO NACIONAL DE PÓS-GRADUAÇÃO E PESQUISA

Educação em Revista | Belo Horizonte | v.27 | n.02 | p.21-40 | ago. 2011 
EM EDUCAÇÃO - ANPED, GE: Educação e Arte, Anais..., n. 01, p. 6.

29 "Creio que existe um terceiro grupo de procedimentos que permite o controle dos discursos. Desta vez, não se trata de dominar os poderes que eles têm, nem de conjurar os acasos de sua aparição; trata-se de determinar as condições de seu funcionamento, de impor aos indivíduos que os pronunciam certo número de regras e assim de não permitir que todo mundo tenha acesso a eles". FOUCAULT, Michel. $A$ ordem do Discurso. São Paulo: Edições Loyola, 1996, p. 36-37.

30 FARINA, Cynthia. Ibid. p. 13.

31 Na célebre entrevista concedida a Claire Parnet e filmada por Pierre-André Boutang em 1988-89, intitulada O abecedário de Gilles Delenze, o filósofo, no capítulo Style, resume o que entende como estilo: criar, buscar no interior da língua uma língua estrangeira, e também levá-la até um limite musical. Outros textos de Deleuze que tratam sobre o assunto estão em Crítica e Clínica. São Paulo: Editora 34, 1997: "A literatura e a vida”, p.11 e "Gaguejou", p. 122.

32 Cf. DELEUZE, Gilles; GUATTARI, Félix. O que é a Filosofia?, p. 262.

33 MELVILLE, Herman. Moby Dick. Trad. Berenice Xavier.Rio de Janeiro: Ediouro, 2001. p. 401.

34 Ibid. p. 37.

35 DELEUZE, Gilles. Conversações. São Paulo: Editora 34, 1992. p. 17.

Recebido: 02/07/2009
Aprovado:19/04/2011
Contato:
Centro Federal de Educação Tecnológica de Pelotas, COLINC.
Praça 20 de Setembro, 455
Centro
CEP 96015-360
Pelotas, RS
Brasil

Educação em Revista | Belo Horizonte | v.27 | n.02 | p.21-40 | ago. 2011 
